\title{
The City of Sevastopol as Part of Russia: Problems of Adaptation and Possibilities of Socio-Political Development (Based on Qualitative Research Materials)
}

\author{
Kirill V. Podyachev* \\ Institute of Sociology \\ of the Russian Academy of Sciences \\ 24/35, Krzhizhanovsky Str., Building 5, Moscow, 117218, Russia
}

Received 22.01.2016, received in revised form 10.02.2016, accepted 28.03.2016

\begin{abstract}
Based on the data obtained during a field survey in June 2015, the article focuses on a number of socio-political problems the city of Sevastopol faced after its accession to the Russian Federation. The author provides examples of the difficulties that arose in the process of Sevastopol citizens' adaptation to a new institutional environment. These are the problems of split in managerial elite, party system instability, local self-government disruption, rejection of a set of educational innovations by the pedagogical community, entrepreneurs' discontent, etc. At the same time the article shows that a key feature of Sevastopol was not affected in the course of adaptation, the feature being a strong corporate spirit and values resulting from pride for the city's heroic history. Thus, reunification of Sevastopol with Russia led to significant institutional changes, which caused some socio-economic difficulties, but all these transformations did not affect the value system of Sevastopol, and they even strengthened it in fact. So, there is every reason to believe that adaptation difficulties will be overcome, and, the policy being reasonable, further development of Sevastopol can be quite successful.
\end{abstract}

Keywords: political science, sociology, Sevastopol, "Russian spring”, civil society, adaptation, social development, integration, activism, value system.

DOI: 10.17516/1997-1370-2016-9-4-986-993.

Research area: sociology.

The Republic of Crimea and the federal city of Sevastopol, new subjects of the Russian Federation, have been in the focus of attention since March 2014. At first, when the media space faced the clash between the euphoria of the "Russian spring", on the one hand, and a hysterical propaganda of the Ukrainian and European media, on the other hand, the abundance of unverified information, rumors, propaganda piping made it extremely difficult to analyze the events in these regions. Today, after the media noise has died down, and the events in Syria being more urgent, the issue of Crimea is overshadowed on the global agenda. This made

(C) Siberian Federal University. All rights reserved

* Corresponding author E-mail address: kirvik@bk.ru 
such analysis possible. Its urgency is primarily due to the significance the events in Crimea and Sevastopol have for modern Russia. Successful development of these regions may be important for successful international policy of Russia and, first of all, for integration processes on the post-Soviet space. The slightest setbacks there (especially the citizens' mass discontent) will be fully used by geopolitical enemies to weaken our country. The objective of social sciences is to study the main problems these regions face and analyze the possibilities of their non-violent, evolutionary settlement.

What should be taken into consideration is extremely poor knowledge of these regions. As for the ideas of what is happening there, that are broadcast through the media and blogosphere, they are mutually contradictory. Therefore they cannot be the basis for a truly scientific analysis of the situation. Only direct on-site work and field researches combining qualitative methods with the principles of the "third sociology" (Shtompka, 2009) and the elements of the intuitive knowledge could provide betterunderstanding of the situation. It should be mentioned that the material presented is primarily based on the interviews ${ }^{1 * * *}$ with the power, education and culture officials and some randomly selected residents of Sevastopol. Thus, only the facts and issues noted by the respondents will be analyzed below whereas the information obtained from other sources is not taken into consideration in the article.

No matter what foreign politicians and media claim, Sevastopol became a part of Russia not just willingly, but with joy and enthusiasm. However, after the euphoria of the "Russian spring" was over, there revealed the problems no one in Sevastopol or Russia previously thought about, the reason being neither low professionalism nor short views. The matter is that no one could expect that the city would become a part of the Russian Federation in the foreseeable future. Therefore, the need to adapt to a new institutional environment led to the complexities. Such adaptation, as far as one can judge from the examples from history, never runs smoothly and painlessly. Even the reforms that ultimately contribute to social development and improvement of the citizens' life result in deterioration of the situation at their initial stage. They can also cause the resistance of those social groups who have to bear the main costs (Przeworski, 1991). Thus, Sevastopol also faced considerable difficulties.

The first one, which is probably the most painful, is the city budget revenue contraction. Previously its main part was accumulated in the city, the revenue being the payment of Russia for renting the Black Sea fleet base. The Ukrainian authorities, investing extremely little money in Crimea, did not dare to encroach on the revenue for fear of separatism explosion. After the accession of Crimea and Sevastopol to the Russian Federation Kharkov agreements were denounced, rent payment was terminated, and the city budget lost the main source of financial income at once. Although resources of Russia are significantly greater than those in Ukraine and the federal government started investing in Sevastopol, the overall level of income has not reached its former level so far. As a result it is necessary to save on everything even though the city needs substantial investments as its infrastructure got extremely worn out over the years the Ukrainian government and is in need of extensive repair works.

Basing on separatism and not trusting the locals, the Ukrainian authorities tried to appoint immigrants from the "mainland", especially from Western regions, to the positions in Sevastopol. These people did not feel their unity with the citizens of Sevastopol and the citizens of Sevastopol themselves were regarded as foreigners. As a result, the psychology of the city top officials turned into that of colonial 
administration, "timeservers" dreaming only of showing their best in front of Kiev to get a higher position "at home". Therefore, on the one hand, they were not concerned about the citizens' interests and the city development. At the same time they greatly feared largescale street protests since the very fact of their occurrence could undermine their reputation in the eyes of the Kiev leaders. It is very similar to the situation we observed in a number of Russian regions (Podyachev, 2012) though it is strongly reinforced. None of the authorities thought of the city development under such conditions as they mostly thought of preventing mass expression of discontent.

At the same time a specific model of "parallel" existence with the power authorities was formed in the civil society. The society tried to solve the problems the authorities did not solve, thus showing an example of a truly activist attitude towards the reality. For example, people would gather and have subbotniks (community work days) to clean dirty streets, they would collect money and plaster the facades that had peeled off without repair works, etc. They tried to do without the authorities in all possible situations. In the situations when it was impossible or when the authorities interfered in their lives, that was quite often, they came out into the streets with the demand to take the citizens' interests into account. This pattern of behavior is opposite to paternalism which is very often ascribed to the Russian people. However, we do not see any classic alienation here when the people's distrust of the authorities turns into civil passivity. At that this socially active community was minimally institutionalized. It was really dangerous to establish any really existing social organizations because the authorities, fearing pro-Russian moods, could exert pressure on them. Therefore, civil society did not form classic NGOs; they established informal communities of the activists united by horizontal network ties (exactly according to M. Castells). They mostly communicated not via the Internet but via more traditional methods, the latter being phone calls and even notes delivered by the boys running from apartment to apartment the way it was done in the XIX century. Institutional sociology failed to identify such communities. That is why one gains the impression that there was no civil society there.

A kind of civilian elite was formed there for more than 20 years of existence of this original social-political model in Sevastopol. It became the main driving force of the "Russian spring". Many of its representatives got their positions in administration after Sevastopol became a part of the Russian Federation.

This caused a significant problem: the Sevastopol civil elite were inexperienced in civil service. They could brilliantly work in an informal environment, but once they turned out to be in the world of bureaucracy it was a very difficult situation for them. As for the lower government bodies, especially "power" ones, they remained the same. It was impossible to replace all government servants due to the lack of appropriately qualified personnel. This resulted in situations when the head, a former activist, supervised those who used to write denunciations to Security Service of Ukraine or were even directly involved in his arrests.

What is worse, Russia sent a considerable number of its officials "to strengthen" the situation, the latter being unfamiliar with local specifics but generally of high opinion of themselves. They considered Crimea and Sevastopol to be "backward" regions that needed to be "pulled up" to the level of "great" Russia. However, whereas the standard of living and economic development might prove this (which was not the fault of the locals as the investments of Ukraine into Crimea and Sevastopol were minimal from 1991), the 
situation concerning culture and civil society self-organization was different. The citizens of Sevastopol were very annoyed by these officials' references to the U.S. and the EU best practices: "What did we flee from Ukraine from? We fled from "Euromaidan" to have no Western order here. But what do they suggest us now?!" Therefore, the officials' reform attempts are rejected by their colleagues among civil activists and the vast majority of the population.

Thus, the social group of Sevastopol civil servants-managers was divided into three subgroups: the "old" ones who worked with the Ukrainian authorities, the "new" ones who were civil activists and the officials sent by the federal authorities, each subgroup being subdivided further. For example, there were the so-called "professional revolutionaries" and "Chalyi's people" among the "new" leaders. The former were organizers of public acts and active fighters against Ukrainization, the latter were representatives of intelligentsia who have always had Pro-Russian position but have never participated in civil movement. Of course, this internal split of Sevastopol managerial elite does not contribute to reducing costs of legal and social adaptation.

The problem in the party system was quite similar. Although Russian political parties rushed to Sevastopol (as well as to Crimea) after it became a part of Russia, only those parties who could rely on party structures that survived through the Ukrainian times, i.e. Edinaia Rossiia (United Russia) and the CPRF, could secure their position there. Such parties like Iabloko (Apple) or Parnassus were not taken any notice of at all. Their position on the accession of Crimea was not welcome, and they were supported only by a circle of fans of the so-called "contemporary art".

There were only two active forces in Sevastopol even in Ukrainian times: the Party of regions and the Communist party. No other parties like Our Ukraine, the Tymoshenko Bloc or the Radical party (O. Lyashko) have ever had support there. Their branches in the city did not exist de facto. But as for the openly Pro-Russian Progressive socialist party (N. Vitrenko), it received sufficient support in Sevastopol, its results in the Ukrainian election campaign remaining within the statistical error.

After the reunification with the Russian Federation the local branch of the Ukrainian Communist party with its entire organizational structure fully moved into the Communist party of the Russian Federation with a tacit approval of the party leaders in Kiev.

The local branch of United Russia was originally formed from civil activists. However, some time later the former members of the Party of regions, who joined United Russia, carried out a decision to expand the Political Council of United Russia and, as a result, intercepted the party leadership.

This situation poses a threat of internal conflict that is a serious challenge for the party. It should be assumed that the administrative resource of United Russia in Sevastopol will not be of some help as its citizens are used to the resistance to the pressure of the authorities, thus, any attempts to use this resource is more likely to repel the voters. It can be assumed that in the future Sevastopol elections can bring a lot of surprises.

The reform of local self-government initiated by the official "outsiders" provokes Sevastopol citizens' numerous questions. According to the respondents, for all the shortcomings of Ukraine, the Ukrainian municipal law was much more convenient and adequate to local realities than the Russian law. Moreover, when part of Ukraine, Sevastopol had a special status. In Russia it became a city of federal importance, the status Moscow and St. Petersburg have. As the Russian 
officials were inexperienced in the organization of the cities of federal importance, the Moscow scheme of local self-government organization was introduced in Sevastopol. According to this scheme municipalities have no great powers, and the city's economy is under the control of the city government. The Moscow scheme did not take into account the specific features of Sevastopol, both social and geographical (the city is indented with bays with no bridges across them that makes transportation between different parts of the city difficult), and this caused problems. At the time of our field research the system of the city's local self-government had not started functioning to its full capacity, not all municipalities had even managed to adopt the rules. In the result the municipalities were withdrawn their powers. Their funding was respectively cut. What they were engaged in were only cultural and leisure activities in fact. To clean the streets or to bury a dead man it was necessary to call the employees from the center, and the latter had to go from afar. It definitely annoyed the citizens.

Another pressure point is education. However, these are not students or their parents but mainly teachers who show their dissatisfaction. There arose two problems in this area - administrative and ideological. The first one is that the headmaster's power in Ukraine is almost absolute. Under the condition of ideological loyalty he / she is almost under no control of administrative authorities. As for the school proper, the headmaster is free in both financial and personnel matters. The ideological control was the only one exercised over the headmaster. It gave no way to "wrong" views questioning the official version of the history of Ukraine. The headmasters in Russia worked under different conditions. They no longer had unlimited access to finances. Neither could they fire teachers at their own discretion, which, of course, caused frustration on their part.
The ideological problem is much deeper. It is that despite all Ukrainian authorities' attempts to implement an "ideologically correct" conception of history and to replace the Russian language by the Ukrainian language at Sevastopol schools the pedagogical community resisted with all their might, sometimes showing the wonders of ingenuity. They showed the same resistance (meeting the parents' sympathy in full) to Yushchenko's attempts to promote such "European values" as "sex education", "rights of the child", etc. in schools. According to the respondents, it was very surprising when after Sevastopol had joined the Russian Federation these attempts were resumed by "people from Moscow and St. Petersburg" (!). This definitely caused serious discontent.

Whereas the solution of the administrative problem implies that the government can rely on pedagogical professional community, not interested in preserving the headmasters' absolute power, the solution of the problem of content necessarily requires a dialogue between teachers and parents as only a dialogue makes it possible to avoid conflict.

However, adaptation processes were most painful for the business community, small business in particular. The entrepreneurs face great difficulties, the main one being sanctions or, rather, inability to be properly credited and insured caused by them. The matter is that there was hardly a Russian Bank or insurance company which had enough courage to take a decision to work in Crimea because of their fear of the problems in Europe. There were also severe problems with logistics due to the absence of bridge and poor sea traffic which got even more aggravated due to the transport blockade initiated by Ukraine.

The absence of land cadastre in Sevastopol also causes serious difficulties as no one bothered to introduce it during the period of independent 
Ukraine existence. As for the Russian land law, it basically proceeds from the existence of cadastre and, thus, fails to take the situation of its absence into account. This was the reason why the processes of plots of land allocation and redistribution stopped, which greatly hinders the development of quite a number of business areas.

Finally, the Russian system of law is more detailed than the Ukrainian one. According to its current requirement, the entrepreneurs themselves or their consultants should have much more professional legal education than they have had before. According to the respondents, the liberal opposition representatives' statements that Ukraine had more freedom contain some truth. But the roots of "freedom" were not of a "democratic character". "Freedom" resulted from a low degree of order, much lower level of administrative organization. Greater focus on details and order in economic activity regulation in Russia may be more favourable in the future than "half-civilized" business environment in Ukraine. Yet, it is so far difficult for the Sevastopol business community to adapt, constant control of various supervising bodies they have never experienced before being the most difficult for them.

However, as far as we can judge basing on the collected data, the Sevastopol business community does not rue the Ukrainian past and has no intention to go back, even despite its members' discontented grumbling which is the most common.

In conclusion, it is important to note that all the difficulties of adaptation mentioned above did not affect value orientations of the citizens of Sevastopol. Their local patriotism, based on the pride for the city's heroic history and associated with the Russian fleet, revealed itself in the Ukrainian authorities' times. It is no less strong now. The "corporate spirit" in the city is also very strong; the residents feel their belonging to
Sevastopol above all and, thus, oppose themselves to the residents of Crimea. "Where do you see Crimean people here?" most of the respondents replied. "Crimean people are those who live in Yalta, whereas people here are Sevastopol citizens". Yet, Sevastopol patriotism is not different from patriotism of the Russian people as Sevastopol has always positioned itself as the city of the Russian glory. Sevastopol identity largely absorbs ethnic and religious differences, uniting people around shared values. The core of the value system is common historical memory, particularly about the events of the Great Patriotic War. The memory also keeps other important historic events connected with the city - St. Prince Vladimir's christening in Chersonese, the Russian Black Sea fleet's victories, defense of Sevastopol during the Crimean war, etc. Solid rejection of Ukrainian nationalism as well as "European values" such as delegitimation of marriage, same-sex relations, cosmopolitanism, etc. is also typical for mass consciousness of the citizens of Sevastopol. The value core is stable, the communities of teachers, cultural workers and civil society activists (with their characteristics noted above) contributing to their preservation. Their efforts resulted in the protection of value system from diffusion even despite the efforts of the Ukrainian propaganda as well as in its imparting to young people.

Therefore, the majority of the Sevastopol citizens believe that they have achieved the right to be a part of Russia through much suffering. They have won it in their struggle. Although some of them feel frustrated from staying in Russia, adaptation problems and the consequent loss of wealth cause discontent especially among trade workers and small entrepreneurs, this discontent being limited to dull grumbling only. Their dissatisfaction with the difficulties they have does not affect their attitude to accession to the Russian Federation as the facts about their desire to return to Ukrainian are not revealed. Besides, 
if the grumbling ones are more in number, it is not they who form the general background of public discourse. The civilian elite mentioned above and its representatives firmly believe that being part of Russia is worth being patient for a while.

The participants of the meeting on the 23 of February 2015 who were mostly local civil activists agreed: "We came to Russia not to be its burden. The country experiences difficulties caused by the sanctions, the latter being undertaken for us. We have no right to be an anchor pulling the country down. We have the right to expect that our interests will be taken into account, but should not expect any privileges, leniency, etc. from the Russian Federation. The Russian Federation has already helped us to leave off the power of the strangers. Now we must help Russia".

Thus, reunification of Sevastopol with Russia has led to significant institutional changes resulting in some socio-economic difficulties. However, all these transformations, if affecting the value system of Sevastopol, strengthened it even more.

Summing up the research issue, it is worth while formulating its main results:

1. Institutional transformation and adaptation to Russian socio-economic and legal environment are very difficult for Sevastopol. However, it is almost always so in similar cases.

2. Despite the costs of the transition period no one (even the entrepreneurs who were mostly affected during a social group transformation) regrets the choice made in March 2014 and is going to demand the return to Ukraine or something like that.

3. The main carriers of local patriotism as well as of firm Pro-Russian moods are humanitarian intelligentsia and the "creative class" (students, engineers, IT employees), - exactly those majority in Moscow and St. Petersburg with Pro-Western, capitulatory positions.

4. The role of local actors (Podyachev, 2014) in Sevastopol is great. It is they who mainly kept historical memory and spiritual and cultural ties with Russia during the Ukrainian authorities' times. They have become the main driving force of the "Russian spring" and still maintain solid network connections thus preserving Sevastopol civil society's high mobilization potential.

5. The majority of the Sevastopol citizens think that reunification with Russia has been achieved through much suffering, and they have nowhere to go from their native home. They regarded the Ukrainian power to be the power of the others. As for the Russian power, they do not consider it as such and are ready for cooperation. However, if the authorities pursue a reformist policy without regard to the citizens' interests, the protests of causal character will not be long in coming. Rich experience in both passive and active resistance to administrative pressure, accumulated by the Sevastopol civic activists, will determine their much larger scale compared to the protests in other regions of the Russian Federation.

\footnotetext{
The respondents were interviewed during the period of 8-18 of June, 2015.
}

\section{References}

Podyachev, K.V. (2012). Protestnoe dvizhenie v Rossii “nulevykh”: genesis i spetsifika [Protest Movement in Russia of the Noughties: Genesis and Specificity], In Vestnik Instituta sotsiologii [Bulletin of Institute of Sociology], 5.

Podyachev, K.V. (2014). K voprosu o roli politicheskikh partii v sisteme gosudarstvennogo i munitsipal'nogo upravleniia v regionakh Rossii [On the Role of Political Parties in the System of State and Municipal Management in the Regions of Russia], In Vlast' (Power), 10, 134. 
Przeworski, A. (1991). Democracy and the Market: Political and Economic Reforms in Eastern Europe and Latin America. New York, Cambridge University Press, 228 p.

Shtompka, P. (2009) V fokuse vnimaniia povsednevnaia zhizn': novyi povorot v sotsiologii [The focus of attention is everyday life], In Sociological studies, 8.

\title{
Город Севастополь в составе России: \\ проблемы адаптации и возможности \\ социально-политического развития \\ (по материалам качественного исследования)
}

\author{
К.В. Подъячев
}

Институт сочиологии Российской академии наук

Россия, 117218, Москва, ул. Кржижановского, 24/35, кор. 5, каб. 502

\begin{abstract}
В статье на основе данных, полученных в ходе полевых исследований в июне 2015 г., рассматривается ряд социально-политических проблем, возникиих в городе Севастополе после его присоединения к Российской Федерации. Автор приводит примеры трудностей, возникающих в процессе адаптации севастопольского общества к новой институциональной среде. Рассматриваются проблемы раскола управленческой элиты, нестабильности партийной системы, дезорганизации местного самоуправления, неприятия педагогическим сообществом ряда новаций в образовании, недовольства предпринимателей и т.п. Одновременно в статье показано, что ключевая особенность Севастополя - сильный корпоративный дух и ценностное ядро, основанное на гордости героической историей города, - не пострадала в ходе адаптации. Таким образом, можно видеть, что хотя воссоединениегорода Севастополя с Россией и привело к существенным институциональным преобразованиям, вызвавшим определённые трудности сочиально-экономического характера, все эти трансформации если и сказались на системе ценностей севастопольцев, то только в сторону ещё большего её укрепления. Поэтому есть все основания полагать, что адаптационные трудности будут преодолены и при разумной политике дальнейшее развитие города Севастополя может быть весьма успешным.
\end{abstract}

Ключевые слова: политология, соииология, Севастополь, «русская весна», гражданское общество, адаптация, соииальное развитие, интеграция, активизм, ценностная система.

Научная специальность: 22.00.00 - сочиологические науки. 